\title{
Socio-economic, Communicational and Psychological Profile of Tribal Farmers for their Livelihood Status in West Nimar Region of Madhya Pradesh, India
}

\author{
Krishna Kumar Rana ${ }^{1 *}$, Arun Kumar ${ }^{1}$, Jitendra Verma ${ }^{1}$ and S.R.K. Singh ${ }^{2}$ \\ ${ }^{1}$ Department of Agriculture Extension Education, BRAUSS, Dr. Ambedkar Nagar (Mhow), \\ M.P., India \\ ${ }^{2}$ Principal Scientist, ATARI, Zone IX-ICAR, Jabalpur, M.P., India \\ *Corresponding author
}

Ke y w o r d s
Agriculture
farming, Diversified
farming,
Livelihood, Tribal
farmer

\section{Keywords}

Agriculture

farming, Diversified

farming,

Livelihood, Tribal

farmer

Article Info

12 July 2019

10 August 2019

\section{A B S T R A C T}

Agriculture is the backbone of the economy. India is a developing country and Agriculture plays a vital role in India's economy. Agriculture and allied activities including crop and animal husbandry, fisheries, forestry and agro processing provides livelihood to the tribal farmers. Diversified farming defines when a farmer is engaged in a multitude of farm enterprises, it is referred to as diversified farming. A farm on which the income from a single product is less than or not equal to 50 per cent of the total income, is called a diversified or general and such farming know as diversified farming. The motive behind diversified farming is self-sufficiency. In view of the objectives of study two types of respondents, agriculture farming and diversified farming were selected. A total 200 tribal farmers in which 100 agriculture farming and 100 diversified farming practicing farmers was selected through snow ball random sampling method from the selected villages. The study was conducted in scheduled block of Khargone district of the Madhya Pradesh. The study were selected following characteristics of tribal farmers like age, education, type of family, size of family, occupation, annual income, housing pattern, land holding, social participation, contact with extension personal and source of information utilization. Scientific orientation, achievement motivation, risk orientation.

\section{Introduction}

Agriculture has been one of the key issues in the global development. With a majority of the rural population in developing countries depending wholly or partially on agriculture, the sector is important for development. The United Nations (2017) projects that world population will grow to 8.6 billion by 2030 and 9.8 billion by 2050 , creating a real need for innovation, entrepreneurship, and leadership in food and agribusiness industries. India is a developing country and Agriculture plays a vital role in India's economy. Indian agriculture is the single largest private enterprise and main occupation that sustain 
livelihood about two-thirds of the population, contributes to overall growth of the economy and provides livelihood and food security to a majority of the population. $54.6 \%$ of the population is engaged in agriculture and allied activities (census 2011) and it contributes $17.4 \%$ to the country's Gross Value Added for the year 2016-17 (at current prices).

Agriculture and allied activities including crop, fruit, animal husbandry, fisheries, forestry and agro processing provides livelihood to the farmers. India has one of the largest concentrations of tribal population in the world. The tribal population of the country, as per 2011 census, is 10.43 crore, constituting $8.6 \%$ of the total population. Tribal's have traditionally lived in fifteen per cent of the country's geographical areas. $89.97 \%$ of them live in rural areas in various ecological and geo climatic conditions ranging from plains, forests, hills, undulating in accessible terrain in plateau areas. Tribal area is rich in natural resources.

A livelihood comprises the capabilities, assets (including both material and social resources) and activities required for a means of living. A livelihood is sustainable when it can cope with and recover from stress and shocks and maintain or enhance its capabilities and assets both now and in the future, while not undermining the natural resource base (Chambers and Conway, 1991). Therefore, keeping the above facts in mind, the present study is entitled as "Socio-economic, Communicational and Psychological profile of Tribal Farmers for their Livelihood status of West Nimar Region (Khargone district) of Madhya Pradesh"

\section{Materials and Methods}

The study was conducted in West Nimar (Khargone district) region of Madhya Pradesh which is under the scheduled area of Madhya
Pradesh state. The total number of Community blocks (CD) in west nimar region is nine. Out of these, six blocks namely, Maheshwar, Segaon, Bhikangaon, Khargone, Bhagawanpura, Jhiranya under the scheduled area. Out of these, one block Bhagwanpura was selected purposively from the selected district because of this block was having maximum tribal population among all other blocks of the district. In first stage a list of villages was collected from selected block headquarter. At the second stage village wise list was arrange on descending order based on agriculture farming and diversified farming practicing by tribal farmers thus, a total ten villages were selected randomly from the list. A list of farmers of ten selected village was prepared. There were two types of respondents ie.100 farmers of agriculture farming and 100 farmer of diversified farming occupation. 10-10 respondents was selected from the each selected villages based on agriculture farming and diversified farming thus a total 200 farmers was selected from the prepared list. The snow ball random sampling technique was used for the study.

A well-structured and pretested interview schedule was used for data collection through personal interview method. Statistical methods like mean, percentage, standard deviation and chi-square test were used for interpretation of the data.

\section{Results and Discussion}

The important characteristics considered for the study were age, education, type of family, size of family, occupation, annual income, housing pattern, social participation, size of land holding, material possession, source of information utilization, contact with extension personal, scientific orientation, achievement motivation and risk orientation. The data analyzed in this respect are presented in Table 1. 
Socio-economic, communicational and psychological profile of tribal farmers

Age

The data in Table 1 indicated that higher number of diversified farming practicing farmers 50.00 per cent were from middle age group followed by young age group 28.00 per cent and 22.00 per cent old age group.

\section{Education}

It is in revealed from Table 1 that higher numbers of the diversified farming practicing farmers 20.00 per cent were found to be Only read and write followed by 19.00 per cent having high school level education, 16.00 per cent had high secondary, 12.00 per cent had primary level of education, 11.00 per cent had illiterate, 8.00 per cent had only read and middle and graduate and above level education was 6.00 per cent.

\section{Type of family}

It is evident from Table 1 that majority of diversified farming farmer 65.00 per cent were belonged to joint family followed by 35.00 per cent belonged to nuclear family.

\section{Size of family}

The data in Table 1 showed that majority of diversified farming practicing farmers 41.00 per cent were belonged to large size of family followed by 34.00 per cent had medium and 25.00 per cent had small size of family.

\section{Occupation}

It is revealed from Table 1 that higher numbers of the diversified farming practicing farmers 67.00 per cent were fully depended on diversified farming followed by 18.00 per cent depended on diversified + service and 15.00 per cent depended on allied activities.

\section{Annual income}

The data in Table 1 showed that majority of tribal farmers $(49.00 \%)$ was found in the medium income category ( $₹ 70,001$ to $₹$ $1,50,000)$ followed by 28.00 per cent farmers in high income category (more than ₹ $1,50,000)$ and 23.00 per cent farmers in low income category (up to ₹ 70,000).

\section{Housing pattern}

It is revealed from Table 1 that majority of diversified farming practicing farmers 32.00 per cent were possess kachha type housing pattern followed by 25.00 per cent had semipucca type housing pattern, 24.00 per cent had pucca and 19.00 per cent had hat type housing pattern.

\section{Social participation}

It is observed from Table 1 that majority of the diversified farming practicing farmers 52.00 per cent had high social participation followed by 27.00 percent had medium and 21.00 percent had low social participation.

\section{Land holding}

From Table 1 showed that higher number of tribal farmers 34.00 per cent were belonged to small size of land holding followed by 24.00 per cent had medium, 22.00 per cent had marginal and 20.00 per cent having large size of land holding.

\section{Material possession}

It is revealed from Table 1 that higher number of diversified farming tribal farmers 50.00 per cent had medium material possession followed by 30.00 per cent had high material possession and 20.00 per cent had low material possession. 
Table.1 Socio-economic, communicational and psychological profile of tribal farmers

\begin{tabular}{|l|l|l|l|l|}
\hline S.N. & \multicolumn{1}{|c|}{ Variables } & \multicolumn{2}{c|}{ Categories } & \multicolumn{2}{c|}{ Diversified farming } \\
(N = 100)
\end{tabular}




\begin{tabular}{|c|c|c|c|c|}
\hline & & Medium & 50 & 50.00 \\
\hline & & High & 30 & 30.00 \\
\hline \multirow[t]{3}{*}{11} & \multirow{3}{*}{$\begin{array}{l}\text { Source of } \\
\text { information } \\
\text { utilization pattern }\end{array}$} & Low & 21 & 21.00 \\
\hline & & Medium & 38 & 38.00 \\
\hline & & High & 41 & 41.00 \\
\hline \multirow[t]{3}{*}{12} & \multirow{3}{*}{$\begin{array}{l}\text { Contact with } \\
\text { extension personal }\end{array}$} & Low & 22 & 22.00 \\
\hline & & Medium & 26 & 26.00 \\
\hline & & High & 52 & 52.00 \\
\hline \multirow[t]{3}{*}{13} & \multirow{3}{*}{$\begin{array}{l}\text { Scientific } \\
\text { orientation }\end{array}$} & Low & 24 & 24.00 \\
\hline & & Medium & 31 & 31.00 \\
\hline & & High & 45 & 45.00 \\
\hline \multirow[t]{3}{*}{14} & \multirow{3}{*}{$\begin{array}{l}\text { Achievement } \\
\text { motivation }\end{array}$} & Low & 19 & 19.00 \\
\hline & & Medium & 35 & 35.00 \\
\hline & & High & 46 & 46.00 \\
\hline \multirow[t]{3}{*}{15} & \multirow[t]{3}{*}{ Risk orientation } & Low & 23 & 23.00 \\
\hline & & Medium & 27 & 27.00 \\
\hline & & High & 50 & 50.00 \\
\hline
\end{tabular}

\section{Source of information utilization (SIU)}

The data presented in Table 1 showed that higher number of tribal farmers 41.00 per cent had high source of information utilization followed by 38.00 per cent had medium source of information utilization and 21.00 per cent had low source of information utilization.

\section{Contact with extension personal}

The data in Table 1 indicated that majority of tribal farmers 52.00 per cent had high contact with extension personal followed by 26.00 per cent had medium contact with extension personal and 22.00 per cent had low contact with extension personal.

\section{Scientific orientation}

From the Table 1 showed that higher number of tribal farmers 45.00 per cent found to high scientific orientation followed by 31.00 per cent had medium scientific orientation and 24.00 per cent had low scientific orientation.

\section{Achievement motivation}

It is revealed from Table 1 that majority of tribal farmers 46.00 per cent found to high achievement motivation followed by 35.00 per cent had medium achievement motivation and 19.00 per cent had low achievement motivation.

\section{Risk orientation}

The data presented in Table 1 showed that majority of tribal farmers 50.00 per cent found to high risk orientation followed by 27.00 per cent had medium risk orientation and 23.00 per cent had low risk orientation.

The result obtained in present study it can be concluded that majority of the diversified farming tribal farmers 50.00 per cent were belonged to middle age group, 20.00 per cent 
were only read and write, 65.00 per cent were belonged to joint type of family, 41.00 per cent were belonged to large size of family, 67.00 per cent tribal farmers were fully depend on diversified farming occupation, 49.00 per cent had medium annual income, 32.00 per cent had kachha type housing pattern, 52.00 per cent had high social participation, 34.00 per cent had small size of land holding, 50.00 per cent had medium material possession, 41.00 per cent had high source of information utilization, 52.00 per cent had high contact with extension personal, 45.00 per cent found to high scientific orientation, 46.00 per cent found to high achievement motivation, 50.00 per cent found to high risk taking ability.

\section{References}

Annual report (2016-17). Department of Agriculture, Cooperation \& Farmers Welfare Ministry of Agriculture \& Farmers Welfare Government of India. Census of India (2011). www.censusindia.net Chambers, R. and Conway, G. R., (1992). Sustainable Rural Livelihoods: Practical
Concepts for the 21st Century. Discussion Paper 296. Institute of Development Studies, London.

Chauhan, N. and M. Nikulsinh. 2011. Role Performance of Tribal Farmwomen in Domestic and Agricultural activities in Gujarat State. Journal of Progressive Agriculture, 2(3): 21-27.

Patel, Prakash L., Salunkhe, Sumit R. and Koli, Mukesh A. (2015). Personal profile of bhil (tribal) farmers for their livelihood status of Nandurbar district in Maharashtra state. Agriculture Update 10(1):12-16.

Planning Commission of India Report, (2010). Migration of Tribal Women: Its Socio- economic Effects - An in depth Study of Chhattisgarh, Jharkhand, M.P and Orissa, by Society for Regional Research and Analysis.

United Nations, Department of Economic and Social Affairs, Population Division (2017). World Population Prospects: The 2017 Revision, Key Findings and Advance Tables. Working Paper No. ESA/P/WP/248.

\section{How to cite this article:}

Krishna Kumar Rana, Arun Kumar1, Jitendra Verma and Singh, S.R.K. 2019. Socio-economic, Communicational and Psychological Profile of Tribal Farmers for their Livelihood Status in West Nimar Region of Madhya Pradesh, India. Int.J.Curr.Microbiol.App.Sci. 8(08): 15641569. doi: https://doi.org/10.20546/ijcmas.2019.808.184 